\title{
Description of the larva of Neocordulia machadoi Santos, Costa \& Carriço, 2010 (Odonata: Corduliidae) from Brazil
}

\author{
César Carriço ${ }^{1,2,3}$, Janira Martins Costa $^{2} \&$ Tatiana Chrysostomo Santos ${ }^{2}$ \\ ${ }^{1}$ Instituto de Biologia, Programa de Pós-graduação em Biologia Animal - PPGBA, \\ Universidade Federal Rural do Rio de Janeiro UFRJ, BR 465, Km 7, \\ CEP 23890 -000, Seropédica, Rio de Janeiro - RJ, Brazil \\ ${ }^{2}$ Departamento de Entomologia, Museu Nacional, Universidade Federal do Rio de Janeiro - UFRJ, \\ Quinta da Boa Vista, São Cristóvão, CEP 20940-040, Rio de Janeiro - RJ, Brazil \\ ${ }^{3}$ Correspondence author: César Carriço, E-mail: carrico82@hotmail.com
}

CARRIÇO, C., COSTA, J.M. \& SANTOS, T.C. Description of the larva of Neocordulia machadoi Santos, Costa \& Carriço, 2010 (Odonata: Corduliidae) from Brazil. Biota Neotrop. 11(2): http://www.biotaneotropica. org.br/v11n2/en/abstract?article+bn01511022011

Abstract: The Larva of Neocordulia machadoi is described and illustrated based on a exuvia collected at Cachoeira da Eubisose stream, São Tomé das Letras, Minas Gerais State, Brazil. With the discovery of this new larva, the number of known Corduliidae larvae is now eight for the Neotropical region.

Keywords: dragonfly, Anisoptera, taxonomy, Brazil.

CARRIÇO, C., COSTA, J.M. \& SANTOS, T.C. Descrição da Larva de Neocordulia machadoi Santos, Costa \& Carriço, 2010 (Odonata: Corduliidae) para o Brasil. Biota Neotrop. 11(2): http://www.biotaneotropica. org.br/v11n2/pt/abstract?article+bn01511022011

Resumo: A larva de Neocordulia machadoi é descrita e ilustrada com base em uma exúvia, coletada no riacho da Cachoeira da Eubiose, São Tomé das Letras, Estado de Minas Gerais, Brasil. Com a descoberta desta nova larva, o número de larvas de Corduliidae é agora oito para a região Neotropical.

Palavras-chave: libélula, Anisoptera, taxonomia, Brasil. 


\section{Introduction}

The genus Neocordulia is represented in Neotropical region by 15 species (Garrison et al., 2006; Costa \& Machado, 2007; Costa et al., 2008, 2010; Santos et al., 2010). Eleven of these species occur in Brazil: N. androgynis (Selys-Longchamps, 1871), N. batesi (SelysLongchamps, 1871), N. carlochagasi Santos, 1967, N fiorentini Costa \& Machado, 2007, N. gaucha Costa \& Machado, 2007, N. machadoi Santos et al., 2010, N. mambucabensis Costa \& Santos, 2000, N. matutuensis Machado, 2005, N. pedroi Costa et al., 2010, N. santacatarinensis Costa et al., 2008 and N. setifera (Hagen in Selys-
Longchamps, 1871). The knowledge of the preimaginal stage is poor, only five of the Brazilian species larvae are known: N. androgynis, N. carloschagasi, N. setifera, $N$. pedroi and N. santacatarinensis.

During an Odonata survey carried out in 2009, in the state of Minas Gerais (Brazil), we collected a larva of Neocordulia in a shallow riffle in low-order stream. The larva was transported to the laboratory, where it was placed in an aquarium with air bubbler. After adult emergence, the larval exuvia was retrieved from the water surface and identified as Neocordulia machadoi. Below we describe this larval exuvia in detail.
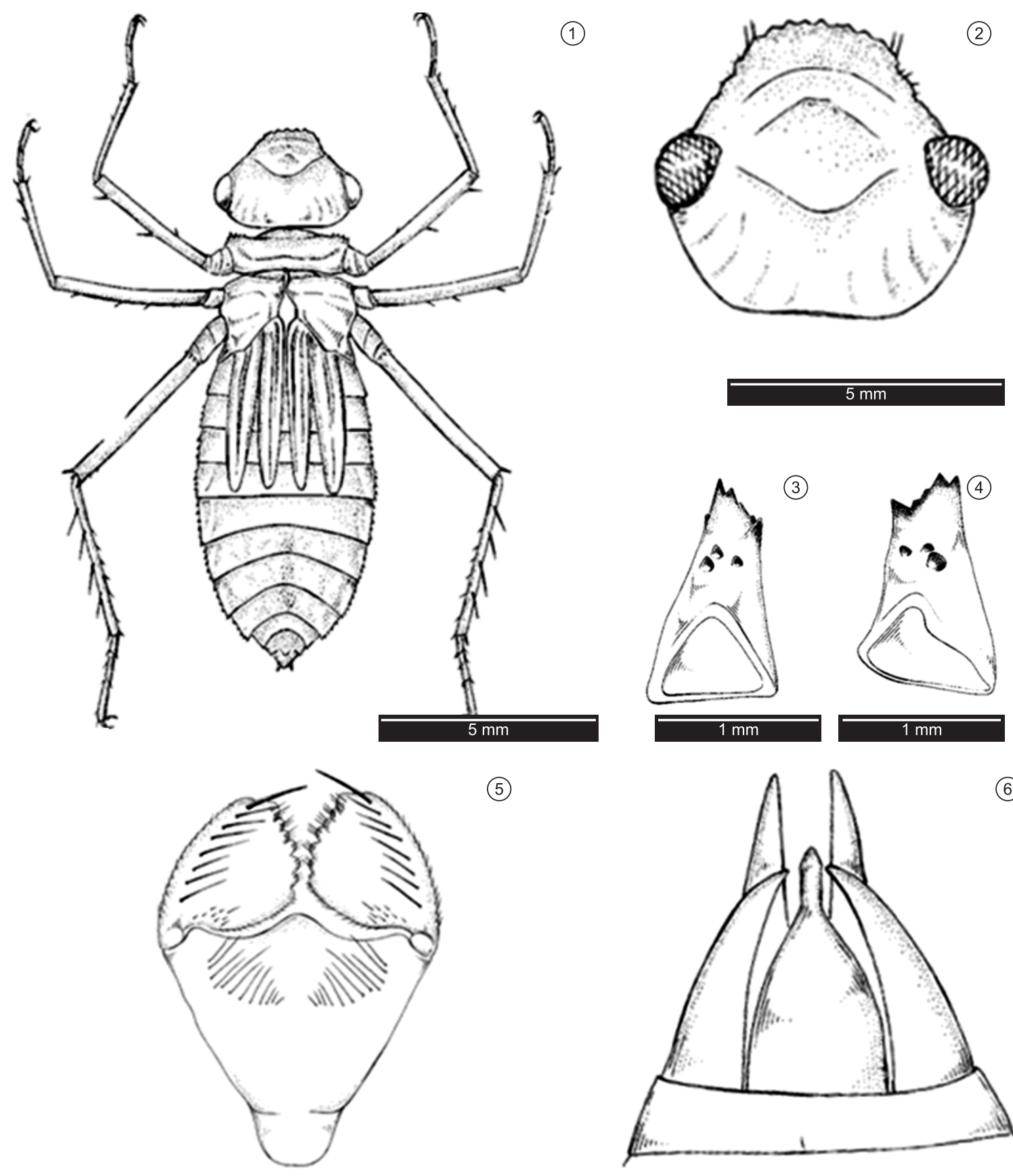

(5)

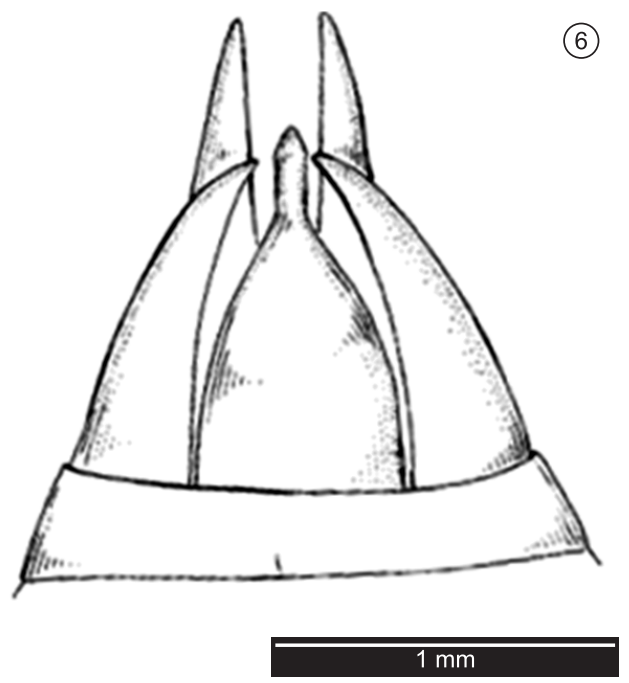

Figure 1-6. Neocordulia machadoi: 1) larva, dorsal view; 2) head, dorsal view; 3) right mandible, inner view; 4) left mandible, inner view; 5) labium and labial palp, ventral view; 6) anal appendages, dorsal view. 


\section{Material and Methods}

The larva of Neocordulia machadoi was collected in the wet season, at São Tomé das Letras, Minas Gerais. The larva was reared during 18 days, emerging on 2.XI.2009. All drawings were made with the aid of a camera lucida attached to a stereoscopic microscope; measurements were made with the aid of a Starrett digital caliper. Terminology for mandibular formula follows Watson (1956). S1-10 refers to abdominal segments 1-10.

The exuvia is deposited in the Departamento de Entomologia, Museu Nacional, Universidade Federal do Rio de Janeiro.

\section{Neocordulia machadoi}

Material examined: Holotype $\delta^{\lambda}$, BRAZIL, Minas Gerais, Cachoeira da Eubiose stream, São Tomé das Letras; $21^{\circ} 43^{\prime}$ 0" S and 44 58' 60” W, 15.X.2009, J.M.Costa \& C. Carriço leg. (emerged 02.XI.2009).

\section{Diagnostic characters:}

The larva of Neocordulia machadoi can be distinguished from all known Neocordulia larvae by having the cerci convergent and abdomen with a blunt apical setae on S6-8.

Larva (Figures 1-6). General shape of body typical of Corduliidae, medium size. General coloration brownish. Compact and robust body, head firmly attached to the thorax. Long legs (Figure 1).

Head (Figures 1-2) small, as wide as long; general shape trapezoidal, as wide as thorax in dorsal view; eyes small, with outer margin strongly rounded. Dorsal crest covered with spatulated setae. Occiput rounded rear slightly concave; posterior corner on each side with less than 10 spatulated setae and many short setae near the eyes. Antennae 7 segmented, dark, segment 6 the longest. Labrum rectangular, fringed with long hairs, brownish. Mandibular formula (Figures 3-4): L1234 0 abd/R1234 y abd. Labium long and wide, reaching metacoxae; prementum (Figure 5) with 12 setae of variable length on each side; ligula triangular; no spines at junction of labial palp with prementum; labial palp triangular with 7 setae; movable hook small; distal margin of palp with 7 crenulations, bearing 3-7 spiniform setae; internal and external margins with many setae.

Thorax. Prothorax rectangular. Wings pads parallel reaching distal margin of S4. Legs long, posterior pair longer than abdomen.

Abdomen. Cylindrical, widest at S5, without dorsal hooks except for a blunt apical setae on S6-8 (Figure 1). Short lateral spines vestigial on S8-9. Anal appendages triangular (Figure 6), acuminate; epiproct in lance-shaped and cerci similar in length and slightly convergent and shorter than epiproct; paraprocts longer than epiproct and cerci.
Measurements (in mm) - Head mediodorsal length: 3; head max. width: 5; prementum length: 6 ; prementum max. width 6 . Femur I: 5; II: 7; III: 9 Tibia I: 5;II: 6; III: 8. Inner wing pads: 5; external wing pads: 6 . Abdomen length with appendages: 12; lateral spines on S8 length: 0.24; lateral spines on S9 length 0.24; epiproct length: 1.3; cercus length:1.5; paraproct length: 3.3. Total length with appendages: 23 .

\section{Acknowledgements}

We are grateful to Angelo B. Machado for helpful review of the manuscript. This paper was supported in part by CAPES, CNPq and FAPERJ.

\section{References}

COSTA, J.M., CARRIÇO, C. \& SANTOS, C.T. 2010. Neocordulia pedroi sp. nov (Odonata: Corduliidae) from southeastern Brazil. Zootaxa 2685:51-56.

COSTA, J.M. \& MACHADO, A.B.M. 2007. Two new species of Neocordulia Selys, 1882 from southern Brazil (Anisoptera: Corduliidae). Lundiana 8(2):143-146.

COSTA, J.M., RAVANELlO, C.T. \& SOUZA-FRANCO, G.M. 2008. Description of a new species of Neocordulia Selys, 1882 (Odonata: Libellulidae, Corduliinae) from Southern Brazil. Zootaxa 1704:64-68.

COSTA, J.M. \& SANTOS, C.T. 2000. Neocordulia mambucabensis spec. nov., a new dragonfly from Rio de Janeiro, Brazil (Anisoptera: Corduliidae). Odonatologica 29(3):247-253.

GARRISON, R.W., Von ELLENRIEDER, N. \& LOUTON, J.A. 2006. Dragonfly genera of the new World: An illustrated and annotated key to the Anisoptera. The Johns Hopkins Univ. Press, Baltimore, p. 1-368.

MACHADO, A.B.M. 2005. Neocordulia matutuensis spec. nov. from Brazil (Anisoptera: Corduliidae). Odonatologica 34(3):299-302.

RÁCENIS, J. 1970. Los Odonatos de la región del Auyatepui y de la Sierra de Lema, en la Guayana Venezolana. 2. Las Familias Gomphidae, Aeshnidae y Corduliidae. Acta Biol. Venezuel. 7(1):23-39.

SANTOS, N.D. 1967. Odonatas de Poços de Caldas, MG. "Neocordulia carlo-chagasi" sp. n. (Odonata: Corduliidae). Atas Soc. Biol. Rio de Janeiro 11:155-202.

SANTOS, T.C., COSTA, J.M. \& CARRIÇO, C. 2010. A new species of Neocordulia Selys, 1882 (Odonata:Corduliidae) from Minas Gerais State, Brazil. Biota Neotrop. 10(2). http://dx.doi.org/10.1590/S167606032010000200011

SELYS-LONGCHAMPS, E. 1871. Synopsis des Cordulines. Bull. Acad. Royal Belg. 31(2):239-316.

WATSON, M.C. 1956. The utilization of mandibular armature in taxonomic studies of anisopterous nymphs. Trans. Amer. Entomol. Soc. 81:155-209. 